\title{
Study on Existing Parking Condition On Major Roads in Salem and Suggestions for Improvement
}

\author{
T. SUBRAMANI ${ }^{1} \quad$ J. JAYALAKSHMI ${ }^{2}$ \\ ${ }^{I}$ Professor \& Dean, Department of Civil Engineering, VMKV Engg College, Vinayaka Missions University, \\ Salem, India \\ ${ }^{2}$ Lecturer, Dhanalakshmi Srinivasan Polytechnic College, Perambalur
}

\begin{abstract}
Salem is the fifth largest city with a population of 7.54 lakhs (2011) in Tamil Nadu. Parking is one of the major problems that are created by the increasing vehicle traffic. It has an impact on transport development. The availability of less space in urban areas has increased demand for parking space especially in central business area. This affects the mode choice also. This has a great economical impact. Two wheeler sales at 15 million are expected to grow 14-15\%, while car sales close to 8 lakhs units a year. In order to accommodate the large volume of vehicle, small cities and towns must develop the affect their infrastructures - roads, flyovers, car parks and other facilities. Otherwise their arteries are most likely to get clogged like it happens in big and mini metros. The solution for this is systemic survey and management of traffic and pedestrian, although at a nascent stage in India, it the one of the options to decongest roads and solve parking and pedestrian problems. Before taking any measures for betterment of conditioned, data regarding availability of parking space, extent of it usage and parking surveys are intended to all these information. Since the duration of parking varies with different vehicles, the data has to be analyzed to access the parking need. As the traffic on the existing road system in the cities increases, congestion becomes serious problem. Thus there could be medium and long term solution measures.
\end{abstract}

Keywords: Improvements, Major roads, Parking condition, Study, Suggestions

\section{GENERAL - NEED FOR PARKING STUDY}

Parking is one of the serious problems that confront the urban planner and traffic engineer. Before any measure for the betterment of the conditions can be formulated basic data pertaining to the availability of parking space, extent of its usage and parking demand are essential. If it is proposed to implement a system of parking charges it will also be necessary to know how much to charge and what will be the affect of the pricing policy on parking. Parking survey is intended to supply all these kind of information.

With the growing population of motor vehicles, the problem of parking has assumed serious proportions. A systematic study of parking characteristic and demand and regulatory measures that are possible for controlling is of great help to a traffic engineers as well as town planner.

As per as survey carried out in India it is roughly estimated that out of 8760 hours in year the car runs for an average for only 400 hours leaving 8360 hours when it is parked. Increasing concentration of human activity on limited land both in terms of residential activity and commercial activity causes the parking problem. Every car owner would wish to park the car as closely as possible to his destination so as to minimize his walking distance. This result in great demand for parking space in central business district (CBD) and other areas where the activities are concentrated.

\section{OBJECTIVES}

- To study existing parking conditions

- To carry out parking studies

- To formulate strategies for better management for parking

\section{LIMITATIONS}

The survey has been carried out only on the working day in the middle of the week. A detailed parking study spread over longer duration of time would have yielded more reliable results. More number of parking problems is especially due to unauthorized construction of the shopping complexes in the in CBD areas; a detailed survey is not carried out.

\section{SCOPE}

There is need to conduct survey on the availability of all vacant spaces both public and private, to explore the possibility of converting such places in to parking areas.

\section{PARKING STUDIES}

Parking is an essential component of the transportation system. Vehicles must park at every destination. A typical automobile is parked 23 hours each day, and uses several parking spaces each week. Parking facilities are a major cost to society and parking conflicts are among the most common problems facing designers, operator, p[lanners and other officials. Such problem can be often defined either in terms of supply (too few spaces are available, somebody must build more) or in terms of management (available facilities are used inefficiently and should be better managed). Management solutions tend to be better than expanding supply because they support more strategic planning. 


\section{PARKING MANAGEMENT OBJECTIVES}

- Reduced development costs and increased affordability.

- Encourage use of alternative modes and reduce motor vehicle use (thereby reducing traffic congestion, accidents and pollution)

- Improved design flexibility, creating more functional and attractive communities.

- Ability to accommodate new uses and respond to new demands.

- Reduced impervious surface and related environmental and aesthetic benefits.

Parking management refers to policies and programs that results in more efficient use of parking resources. Parking management includes several specific strategies; nearly two dozen are described in this report. When appropriately applied parking management can significantly reduce the number of parking spaces required in a particular situation, providing a variety of economic, social and environmental benefits. When all impacts are considered, improved management is often the best solution to parking problems.

\section{STUDY OF PAST AND PRESENT CONDITIONS IN SALEM CITY}

\section{A. Salem - General}

Salem is the fifth largest city in Tamil Nadu over an area of 91.34 Sq.kms. Salem city is located at distance of $350 \mathrm{kms}$ from a Chennai on the west, and $160 \mathrm{kms}$ from Coimbatore and it got the fifth largest population of 7.54 lakhs as per 2011 census in Tamil Nadu.. It is situated at the trijunction of Bangalore, Trichirappalli and Chennai roads. The City is located at $1140^{\prime}$ 'North and $7810^{\prime}$ on the East. The general topography is plain The city is surrounded by the hills viz. the shervarous and Nagarmalai on the North, The Kanjamalai on the west, the Goodamalai on the East.

\section{B. Population Growth}

The population in Salem has grown at a rate of 23 percent per decade between 1951 and 1971, the rate has been lower for the decade $1971-1981$ at 17 percent and 14 percent per decade between 1991 and 2011. TABLE. 1 gives the growth of population within the Salem town. Population growth of Salem City Corporation given in Table 1.

\section{Existing Land-Use Structures}

The extent of Salem town is 91.34 Sq.km of this the developed area is 4648 Hectares i.e. 48.71 percent of the total area and undeveloped area is 4894 hectares i.e. 51.29 per cent of the total area. Figure. 1. is showing the existing land use details of Salem City Corporation area.

\section{SALEM CITY CORPORATION ROAD NETWORK}

Salem district as a whole has only $10,133.7 \mathrm{~km}$. of road, out of which $214.6 \mathrm{~km}$ are cement concrete roads, $5098.1 \mathrm{kms}$. are bituminous surfaced road and the remaining $4821 \mathrm{kms}$. are water Bound Macadam roads. The unsurfaced road of $2352.7 \mathrm{kms}$. also exist in the district

\section{TABLE 1. POPULATION GROWTH OF SALEM} CITY CORPORATION

\begin{tabular}{|l|c|c|c|}
\hline Year & $\begin{array}{c}\text { Salem town } \\
\text { / corporation* } \\
\text { population }\end{array}$ & $\begin{array}{c}\text { Decade } \\
\text { variation }\end{array}$ & $\begin{array}{c}\% \text { of } \\
\text { decade } \\
\text { variation }\end{array}$ \\
\hline 1901 & 70621 & - & - \\
\hline 1911 & 59153 & $(-) 11468$ & $(-) 16.24$ \\
\hline 1921 & 52244 & $(-) 6909$ & $(-) 11.68$ \\
\hline 1931 & 102149 & $(-) 49935$ & 95.58 \\
\hline 1941 & 129702 & 27523 & 26.94 \\
\hline 1951 & 202335 & 72633 & 56 \\
\hline 1961 & 249145 & 46810 & 23.13 \\
\hline 1971 & 308716 & 59571 & 23.9 \\
\hline 1981 & 361394 & 52678 & 17.06 \\
\hline $1991^{*}$ & 579951 & 218557 & 60.47 \\
\hline $2001^{*}$ & 672330 & 92379 & 15.92 \\
\hline $2011^{*}$ & 754000 & 81670 & 12.15 \\
\hline
\end{tabular}

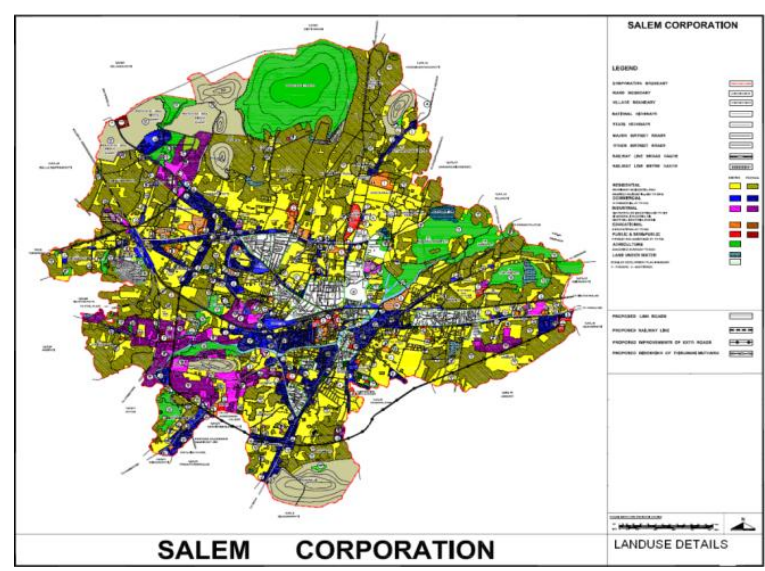

\section{FIGURE.1. EXISTING LAND-USE DETAILS OF SALEM CITY CORPORATION}

Salem Corporation has about $748.13 \mathrm{kms}$. of surfaced roads under its control and maintenance as detailed

\section{TABLE. 2 TYPES OF ROADS WITH THEIR LENGTH IN SALEM CORPORATION}

\begin{tabular}{|r|l|l|}
\hline $\begin{array}{l}\text { Sl. } \\
\text { No }\end{array}$ & Category & $\begin{array}{l}\text { Road } \\
\text { length } \\
(\mathbf{k m})\end{array}$ \\
\hline 1 & Cement Concrete Super Roads & 54.47 \\
\hline 2 & Black Topped Roads & 628.17 \\
\hline 3 & Wbm Roads & 17.04 \\
\hline 4 & Earthern Road & 23.46 \\
\hline 5 & Others & 24.66 \\
\hline & Total Length of Municipal Roads & 748.13 \\
\hline
\end{tabular}

below. The width of road ranges from $3.5 \mathrm{~m}$ to $14.0 \mathrm{~m}$ in the major road network excluding the lanes and small roads. 
The details of the various categories of roads with their lengths in the town is show in TABLE. 2. Fig.2. shows the identified road network of Salem city.

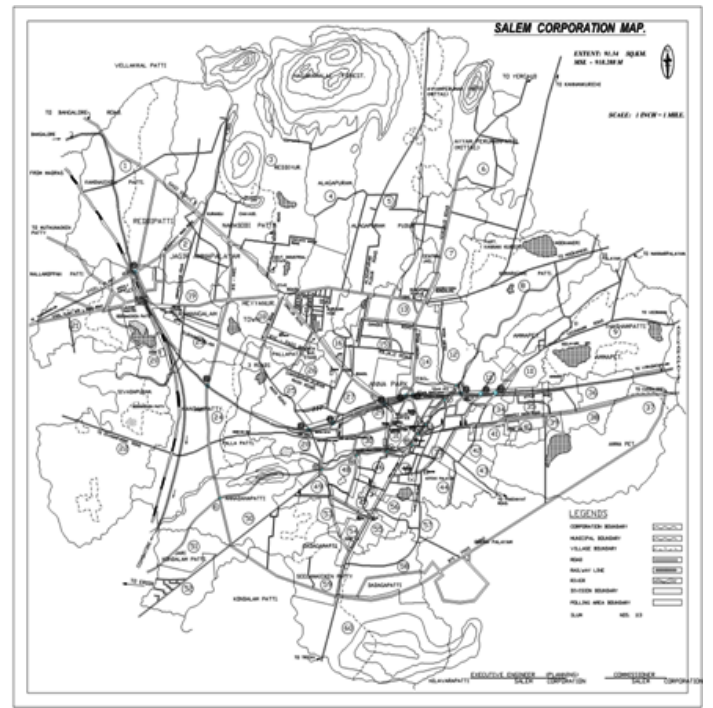

\section{FIGURE.2. SALEM CITY CORPORATION ROAD NETWORK}

\section{PARKING STUDIES}

\subsection{PARKING CHARACTERISTICS Parking accumulation:}

It is defines as the number of vehicle parked at a given instant of time. Normally this is expressed by accumulation curve. Accumulation curve is a graph obtained by plotting the numbers of bays occupied with respect to time.

\section{Parking volume:}

Parking volume is the total number of vehicle parked at a given duration of time. This does not account for repetition of vehicles. The actual volume of vehicles entered in the area is recorded.

\section{Parking load:}

parking load gives the area under the accumulation curve. It can also be obtained by simply multiplying the numbers of vehicles occupying the parking area at each time interval with the time interval. It is expressed as vehicle hour.

\section{Average parking duration:}

It is the ratio of total vehicle hours to the number of vehicles parked.

$$
\text { Parking duration }=\frac{\text { Parking load }}{\text { Parking volume }}
$$

\section{Parking turnover:}

It is the ratio of number of vehicles parked in duration to the number of parking bays available.

$$
\text { Parking duration }=\frac{\text { Parking volume }}{\text { Number of bays av ailable }}
$$

This can be expressed as number of vehicles per day per time requirement.

\section{Parking Requirement}

There is some minimum parking requirement for different types of building

- For residential plotless than 300 Sq.m. only community parking space is required.

- For residential plaot area from 500 to 1000 Sq.m, minimum onefourth of the open area should be resereved for parking.

- Offices may require atleast one space for every 70Sq.m Parking area.

- One parking space is enough for 10 seats in a resturant

- $\quad$ where as theatres and cinema halls need to keep only one parking space for 20 seats.

Thus the parking requirement is different for different landuse zones.

\subsection{TYPES OF PARKING SURVEYS}

Parking surveys are conducted to collect the above said parking statistics. The most common parking surveys conducted are:

\section{In-out survey:}

In this survey the occupancy count in the selected parking lot is taken at the beginning. Then the number of vehicles that enter the parking lot for a particular time interval is counted. The number of vehicle that leaves the parking lot is also taken. The final occupancy in the parking lot is also taken. Here the labour required is very less. Only one person may be enough. But we won't get any data regarding the time duration for which a particular vehicle use that parking lot. Parking duration and turnover is not obtained. Hence we cannot estimate the parking fare from this survey.

\section{Fixed period sampling:}

this is almost similar to in-out survey. All vehicles are counted at the beginning of the survey. Han after a fixed time interval that may vary between 15 minutes to 1 hour, the count is again taken. Here there are chances of missing the number of vehicles that were parked for a short duration.

\section{License plate method of survey:}

this results in the most accurate and realistic data. In this case of survey, every parking stall is monitored at a continuous interval of 15 minutes or so and the license plate number is noted down. This will give the data regarding the duration for which a particular vehicle was using the parking bay. This will help in calculating the fare because fare is estimated based on the duration for which the vehicle was parked. If the time interval is shorter, than there are less chances of missing short term parkers. But this method is very labour intensive.

\section{ILL EFFECTS OF PARKING}

\section{A. Congestion:}

Parking takes considerable street space leading to the lowering of the road capacity.Hence, speed will be 
reduced,Journey time and delay will also subsequently increase. The operational cost of the vehicle increases leading great economical loss to the community.Mixed type of parking shown in Figure.3. \& Figure.4.shows that there is no proper parking bays in Salem.

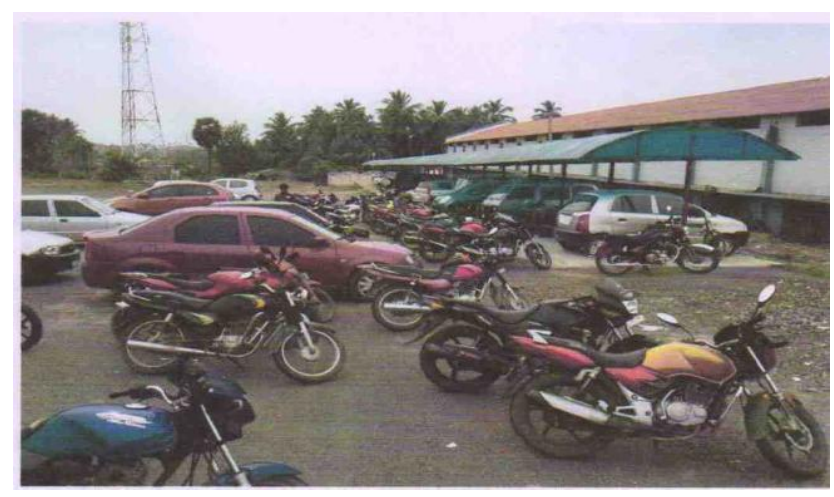

FIGURE.3. MIXED TYPE PARKING (2 WHEELER \& 4 WHEELER)

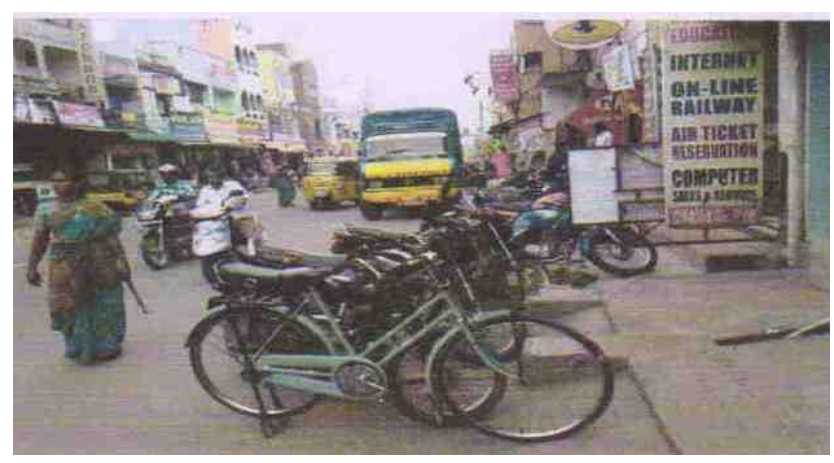

\section{FIGURE.4. NO PROPER PARKING BAYS}

\section{B. Accident}

Careless maneuvering of parking and un-parking leads to accidents which are referred to as accidents. Common type of parking accidents occur while driving out a car from the parked area, careless opening of doors of parked cars, (Figure.5.) and while bringing in the vehicle to the parking lot for parking.

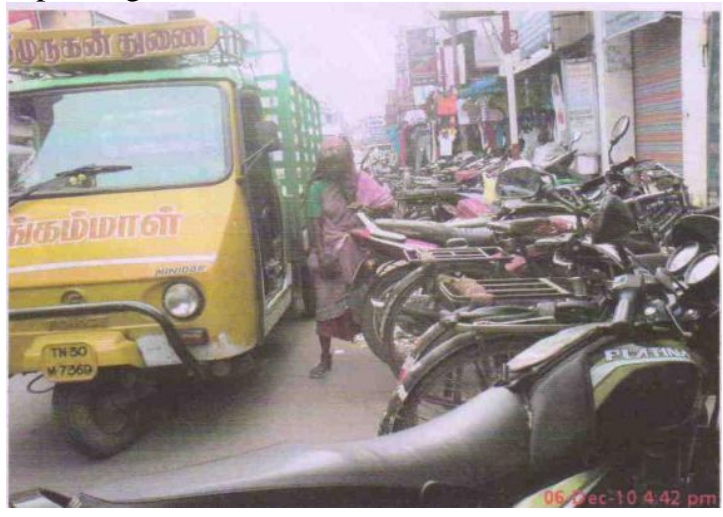

FIGURE.5 ACCIDENT POSSIBILITY IN PARKING

\section{Environment pollution}

They also cause pollution to the environment because stopping and starting of vehicle while parking and unparking results are noise and fumes(Figure.6.). They also affect the aesthetic beauty of the building because car parked at every available space creates a feeling that building rises from plinth of cars. Sometimes they obstruct the fire fighting vehicles. Also they block access to hydrants and access to building.

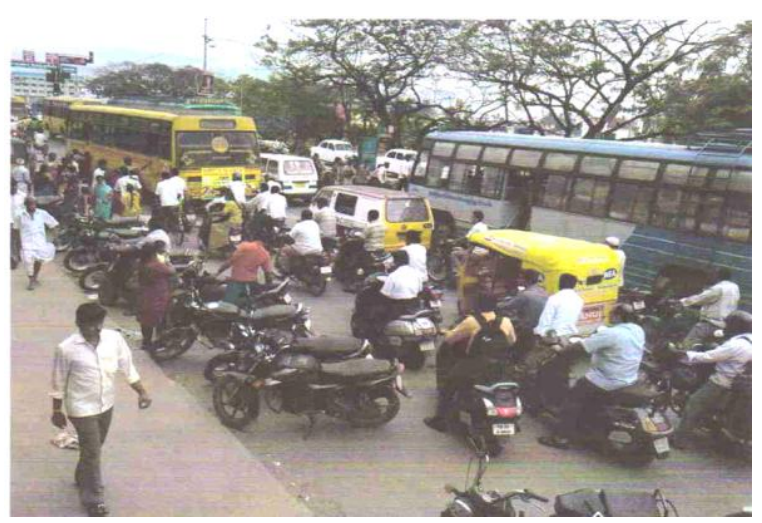

\section{FIGURE.6. ENVIRONMENTAL POLLUTION POSSIBILITY}

\section{PARKING STUDIES AND ANALYSIS OF DATA}

Parking survey were conducted in 15 places to study the existing parking traffic condition

\subsection{Five road:}

It is observed that peak parking hours in between 11.3.am to $1 \mathrm{pm}$. Parking lot is provided on one side of the road. Parking supply for two wheeler is 30 and demand is 27, supply is meeting the demand. No parking for four wheeler. Parking accumulation graph shown in Figure.7.

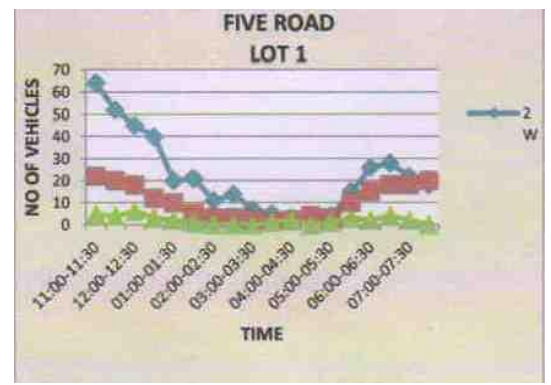

\section{FIGURE.7. PARKING ACCUMULATION GRAPH}

\subsection{Old bus stand:}

It is observed that peak parking hour is between $10.30 \mathrm{am}$ to $2 \mathrm{pm}$. Supply for two wheeler and three wheeler is 300 and 80 respectively. Parking demand for two wheeler and three wheeler is 280 and 60, supply is meeting the demand. Parking accumulation graph shown in Figure.8. 


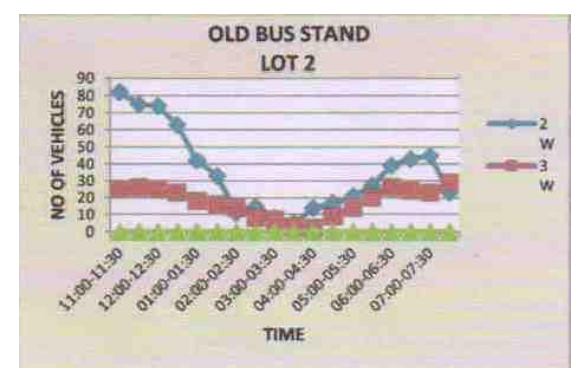

\section{FIGURE.8. PARKING ACCUMULATION GRAPH}

\subsection{Four Road}

It is observed that the peak parking hour is between 11.00am to $3.00 \mathrm{pm}$. No proper parking bays are provided. The parking supply for four wheeler is 115 and the demand is 118 , hence supply is not meeting the demand. Parking accumulation graph shown in Figure.9.

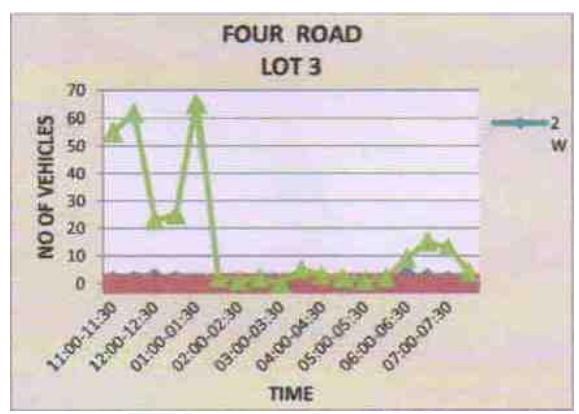

\section{FIGURE.9. PARKING ACCUMULATION GRAPH}

\subsection{Saradha College Road}

It is observed that the peak parking hours is between $11.00 \mathrm{am}$ to $2.00 \mathrm{pm}$. parking is available on one side of the road. The parking supply for two wheeler is 65 and the demand is 69, hence supply is not meeting the demand.|Parking accumulation graph shown in Figure.10.

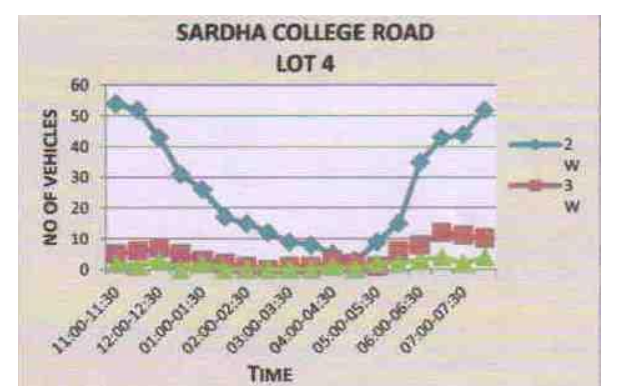

\section{FIGURE.10. PARKING ACCUMULATION GRAPH}

\subsection{State Bank Colony}

It is observed that peak parking hours is between $4.30 \mathrm{pm}$ to $7.30 \mathrm{pm}$. Parking demand increases. Parking place andfacility is limited. Parking accumulation graph shown in Figure.11.

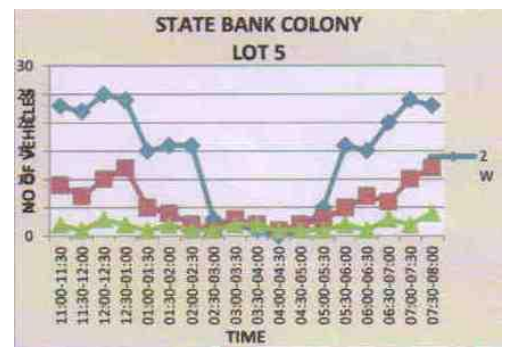

\section{FIGURE.11. PARKING ACCUMULATION GRAPH}

\subsection{Cherry Road}

No parking facility is available on both side of the road. Railing is provided on one side of the road. Zebra crossing is availableParking accumulation graph shown in Figure.12.

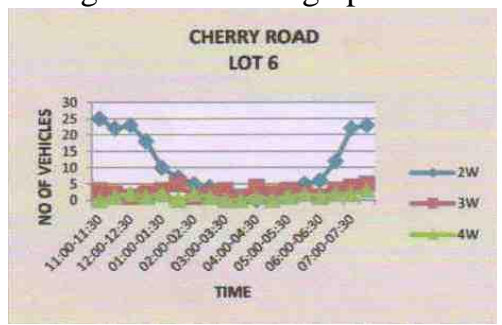

\section{FIGURE.12. PARKING ACCUMULATION GRAPH}

\subsection{Permanur Road}

Both side parking is available. There is no three and four wheeler parking; only two wheeler parking is available. The parking supply for two wheeler is 16 and the demand is 18 , hence supply is not meeting the demand. Parking accumulation graph shown in Figure.13.

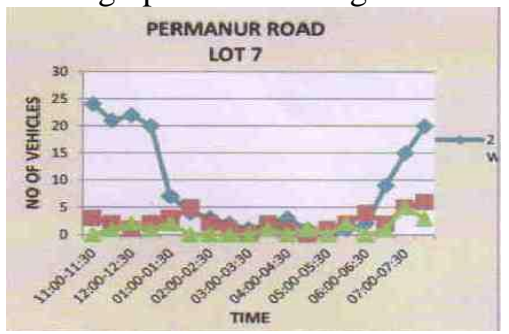

\section{FIGURE.13. PARKING ACCUMULATION GRAPH}

\subsection{Sks Hospital Road}

It is observed that peak parking hours is between $11.00 \mathrm{am}$ to $01.00 \mathrm{pm}$. parking for two wheeler is available No three and four wheeler parking. The parking supply for two wheeler is 30 and the demand is 38 , hence supply is not meeting the demand. Parking accumulation graph shown in Figure.14.

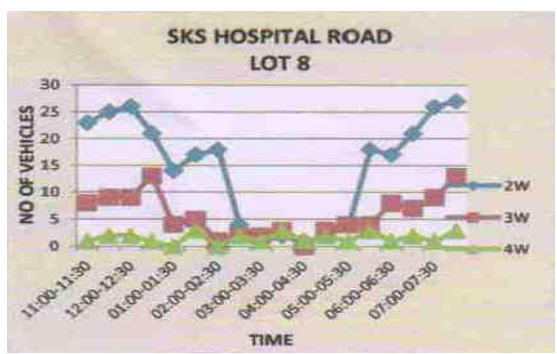

FIGURE.14. PARKING ACCUMULATION GRAPH 


\subsection{Bangalore Bye-Pass Road}

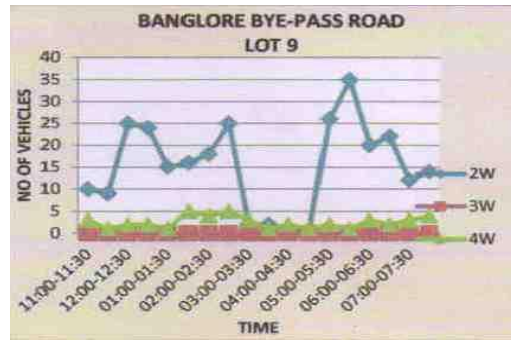

\section{FIGURE.15. PARKING ACCUMULATION GRAPH}

No proper parking bays for two and four wheeler. It is observed that peak hours is between $3.00 \mathrm{pm}$ to $7.00 \mathrm{pm}$. parking demand increases on Sunday due to Sunday bazaar. Parking accumulation graph shown in Figure.15.

\subsection{Railway Station}

Parking place is available for two, three and four wheeler. It is observed that peak parking hours is between $11.00 \mathrm{am}$ to $2.00 \mathrm{pm}$. The parking supply for two wheeler and four wheeler are 42 and 25 respectively. The demand for two wheeler and four wheeler is found to be 37 and 21 respectively. Hence supply is meeting the demand. Parking accumulation graph shown in Figure.16.

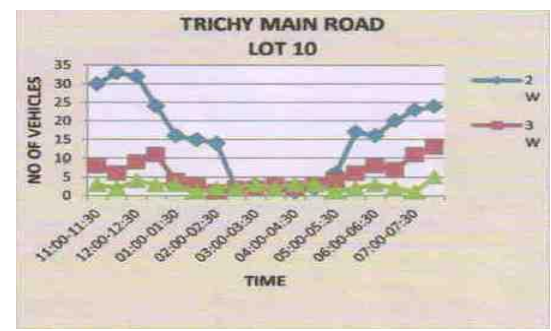

\section{FIGURE.16. PARKING ACCUMULATION GRAPH}

\subsection{Bazzar Street}

It is observed that peak parking hours is between $7.00 \mathrm{pm}$ to $07.30 \mathrm{pm}$. parking for two wheeler is available. No three and four wheeler parking. The parking supply for two wheeler is 35 and the demand is 62 . Hence supply is not meeting the demand. Parking accumulation graph shown in Figure.17.

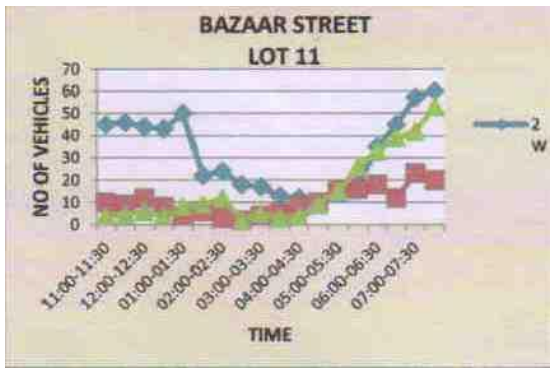

FIGURE.17. PARKING ACCUMULATION GRAPH

\subsection{Railway Station}

It is observed that the peak parking hours is between $11.00 \mathrm{am}$ to $2.00 \mathrm{pm}$. parking is available on one side of the road. The parking supply for two wheeler is 40 and the demand is 44 , hence supply is not meeting the demand. Parking accumulation graph shown in Figure.18.

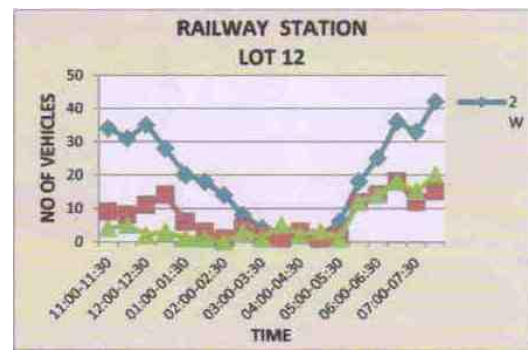

\section{FIGURE.18. PARKING ACCUMULATION GRAPH}

\subsection{New Bus Stand}

Parking place is available for two and four wheeler. It is observed that peak parking hours is between $05.30 \mathrm{pm}$ to $08.30 \mathrm{pm}$. The parking bays are provided at inclined angle. The parking supply fort two wheeler and four wheeler are 79 and 55 respectively. The demand for two wheeler and four wheeler is found to be 83 and 62 respectively. Hence supply is not meeting the demand. Parking accumulation graph shown in Figure.19.

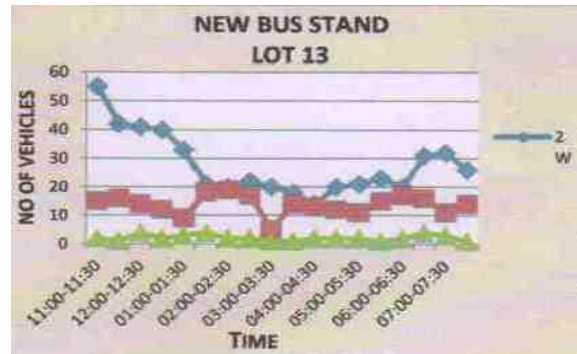

\section{FIGURE.19. PARKING ACCUMULATION GRAPH}

\subsection{Meyyanur Main Road}

It is observed that peak parking hours is between $11.00 \mathrm{am}$ to $01.00 \mathrm{pm}$. parking for two wheeler is available. No three and four wheeler parking. The parking supply for two wheeler is 30 and the demand is 27 , hence supply is not meeting the demand. Parking accumulation graph shown in Figure.20.

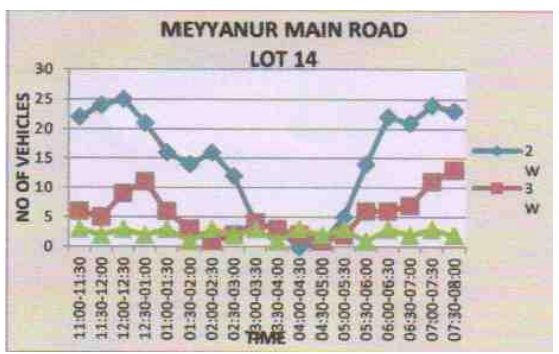

FIGURE.20. PARKING ACCUMULATION GRAPH

\subsection{Kondalampatti}

Both side parking is available. There is no three and four wheeler parking; only two wheeler parking is available. The parking supply for two wheeler is 25 and the demand is 27 , hence supply is not meeting the demand. Parking accumulation graph shown in Figure.21. 


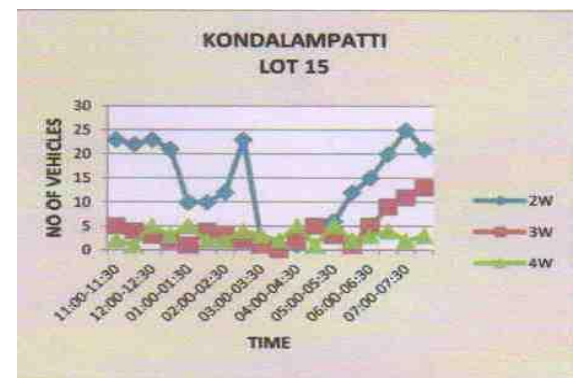

\section{FIGURE.21. PARKING ACCUMULATION GRAPH}

\section{CONCLUSION}

Parking takes considerable street space leading to the lowering of the road capacity. Hence, speed will be reduced, Journey time and delay will also subsequently increase. The operational cost of the vehicle increases leading great economical loss to the community. According to the parking study on existing traffic condition on the road network it is must and required to remove onstreet parking system for efficient transportation system. Careless maneuvering of parking and un-parking leads to accidents which are referred to as accidents. Common type of parking accidents occur while driving out a car from the parked area, careless opening of doors of parked cars, and while bringing in the vehicle to the parking lot for parking. They also cause pollution to the environment because stopping and starting of vehicle while parking and un-parking results are noise and fumes

To reduce the parking of vehicles we can implement the following.

- $\quad$ For short term measures pay and park method will be done at peak hours to control and regulate the parking.

- For long term measures Off street parking have to be provided near CBD areas, within the radius of 1 $\mathrm{Km}$.

\section{SUGGESTIONS FOR IMPROVEMENT}

Though on street parking is an extravagant use of the precious space, it cannot be entirely prohibited. A judicious application of appropriate traffic management measures will help to mitigate some of the ill effects of on street parking. These measures should be of a comprehensive parking policy for the city. The regulatory measures range from waiting restrictions in a street to the comprehensive control over an extended area, lying down where the vehicles may or may not park, what should be the parking tome and charges should be levied for parking. The measures should be periodically reviewed and altered, if necessary. The regulatory measures are generally of two types, one where the use of parking space is authorized for certain periods free or for payment and other where parking is prohibited, but which allows parking for picking up or setting down the goods and passengers. When a controlled parking scheme is planned, the zone boundaries should be delineated and suitable traffic signs are installed. While on street parking and its regulations will be an important aspect of the overall development of land use and building activities adequately take care of parking needs is to promulgate ordinance whereby all new or remolded building will require having within their cartilage or prescribing parking space. Parking places are designed at desirable location alone, and no parking is permitted elsewhere, the measure will be successful only if the streets are probably signed and the carriageway marking are adequate.

Angle parking seems to be better than parallel parking which is usually involves a backing motion. Delay of traffic is minimized with angle parking. Regulation of parking by charging fees has the desirable effect of curbing long term parking, while encouraging short term parking. One method of collecting the charges is by installing parking meters.

\section{REFERENCES}

[1]. DTCP (1986), 'Short term improvement program ME Traffic and Transportation study for Coimbatore, Madurai, Trichy and Salem', DTCP, Tamil Nadu

[2]. Hanspeter Georgi (1973), 'Cost-Benefit Analysis and Public Investments in Transport: A Survey', First Edition, Butter Worths (Publishers),London.

[3]. Kadiyali.L.R.(2007), 'Traffic Engineering and Transport Planning', $7^{\text {th }}$ edition, Khanna publishers, Delhi.

[4]. Khanna S.K - Justo C.E.G (2010), Highway Engineering', $9^{\text {th }}$ edition, Nem Chand and Bros. publishers, Roorkee(U.P)

[5]. Lindsay R. Peat (1982), Practical Guide to DBMS selection', Walter de Grawyter, New York.

[6]. Meyer M.d.Miller E.J (1984),'Urban Transportation Planning', Mcgraw - Hill series, New Delhi.

[7]. V.N.Vazirani \& S.P.Chandola, 'Transportation Engineering Vol.I ', $5^{\text {th }}$ edition, Khanna Publishers, New Delhi

[8]. Dr.L.R.Kadyali \& Dr.N.B.Lal, Principles and Practices of Highway Engineering, $5^{\text {th }}$ edition, Khanna Publishers, New Delhi

[9]. B.L.Gupta \& Amit Gupta `Highway and bridge Engineering ' ${ }^{\text {rd }}$ edition Standard Publishers Distributers, New Delhi

[10]. C.Jotin Khisty \& B.Kent Lall, Transportation Engineering' $3^{\text {rd }}$ edition, PHI Learning Private Limited, New Delhi

[11]. Gurcharan Singh, 'Highway Engineering'5 'rd edition Standard Publishers Distributers, New Delhi

[12]. R.K. Khitoliya, 'Principles of Highway Engineering' $1^{\text {st }}$ edition, Dhanpat Rai Publishing Company, New Delhi.

[13]. DTCP (1999), 'Comprehensive Traffic and Transportation Study for Salem', Pallavan Transport Consultancy Services Ltd., Chennai, Tamil Nadu.

[14]. Guidelines on regulation and control mixed traffic in urban areas, IRC: 70-1977. 